Anais do III Simpósio de Educação e Cultura Corporal Universidade do Oeste Paulista - Presidente Prudente - 2018

https://www.sympla.com.br/iii-simposio-de-educacao-e-cultura-corporal__296060

\title{
EXPERIÊNCIAS MOTIVACIONAIS NA PRÁTICA ESPORTIVA
}

Mauricio Bueno da Rosa

Eliane Bitencourt

Resumo: O objetivo deste estudo é tratar de um dos campos com grandes volumes de publicações e de maior interesse, ou seja, as motivações no esporte e na atividade física. Em muitos momentos aparece a pergunta sobre qual o motivo ou motivos que fazem com que certos atletas não optem por uma vida mais sedentária e em princípio confortável, para escolher sacrificar muito do seu tempo e dedicar esforços para a prática de esportes. Do mesmo modo, levanta-se a discussão sobre a influência da motivação para o sucesso no esporte, com base em que ponto um atleta pode alcançar um nível mais elevado sem ter a necessária motivação. Com relação a esse último sentido, houve grande impacto do aumento da profissionalização da prática de atividade físico-esportiva na propagação das ciências que têm seus estudos voltados para a motivação, tais como a psicologia do esporte entre outras.

Palavras-chave: Habilidades psicológicas, motivação, recursos motivacionais, prática esportiva.

\section{Introdução}

Por causa de todos esses motivos, tornou-se um objeto de interesse crescente os assuntos sobre a motivação no esporte, com o intuito contínuo de desenvolver estratégias motivacionais que descompliquem a intervenção nos dois níveis mencionados anteriormente, tais como ampliar a adesão em diversos programas de esportes, indagando se uma ideal preparação psicológica estaria destinada a alcançar níveis elevados de performance no esporte competitivo.

Ocasionalmente, tanto a excitação quanto a ativação emocional têm sido relacionadas de maneiras equivocadas com a motivação. Desse modo, existiam alguns treinadores que desejavam ampliar os níveis de ativação dos atletas antes dos jogos, acreditando assim que essas atitudes teriam um impacto positivo na motivação dos atletas; mas, na realidade isso não acontece. Diante desse panorama, observa-se que motivação e ativação não devem ser confundidas porque são conceitos diferentes.

Do mesmo modo, ao estudar o comportamento motivado no esporte é um erro muito prejudicial e corriqueiro identificar a motivação com as causas totais do comportamento. Ainda que sejam essenciais as variáveis motivacionais nessa área, tanto para o treinamento e performance quanto para o aprendizado, deve-se aceitar que os fatores motivacionais não são os únicos responsáveis por afetar o comportamento, e verifica-se que nem todas as variáveis motivacionais serão semelhantemente fáceis modificar. 
Anais do III Simpósio de Educação e Cultura Corporal

Universidade do Oeste Paulista - Presidente Prudente - 2018

https://www.sympla.com.br/iii-simposio-de-educacao-e-cultura-corporal__296060

\section{Desenvolvimento}

Em resumo, a motivação faz com que a pessoa se comporte e aja de determinada forma. Seria uma "reunião de processos psicológicos, intelectuais e fisiológicos que toma uma decisão, em determinada situação, de quão fortemente a pessoa age e em qual direção sua energia será direcionada.

Pode-se também definir como "os fatores que sustentam, causam e canalizam o comportamento dos seres humanos em um sentido comprometido e particular" ${ }^{2}$, ou seria como "um termo genérico que se dirigiria a um amplo conjunto de necessidades, forças, impulsos, desejos”. De um modo geral, todas essas definições estariam concentradas na direção do comportamento do ser humano e na quantidade de energia. Talvez, a definição de Littman seja a mais completa, quando foi formulada em 1958, quando apontou: A motivação pode se referir à condição ou processo que pode ser psicológico ou fisiológico, adquirida ou inata, externa ou interna ao organismo, descrevendo ou determinando o quanto ao "quê" e "porquê" um comportamento é encerrado, orientado, mantido ou determinado; refere-se também esse fenômeno ao estado no qual determinado comportamento é desejado ou alcançado de maneira frequente; relaciona-se também ao fato de que uma pessoa irá esquecer, aprender ou lembrar de determinado material com base no significado e importância que a pessoa fornece a cada situação."

Identifica-se que a dificuldade em definir a motivação apenas com um único termo vincula-se com a quantidade de teorias que foram elaboradas sobre ela.

\section{Considerações finais}

A forma mais eficaz de motivação é o compromisso sincero e entusiasta de seus jogadores para alcançar um objetivo comum. Deve ser levado em conta que a variedade motiva os jogadores, então o treinador deve usar procedimentos de motivação variados. Também é importante lembrar que existe alguma segurança quando os jogadores sabem o que vai acontecer, então o treinador deve sempre evitar usar o mesmo tipo de segurança para manter os jogadores constantemente motivados. As razões fundamentais para motivar os atletas seriam: $\mathrm{O}$ jogador procura reconhecimento. $\mathrm{O}$ jogador quer se sentir forte. Em certos casos, você também pode tentar satisfazer o desejo de seus pais, amigos ou qualquer outra pessoa. 


\section{Referências}

CONFEF. Atividade física: sinônimo de bem-estar. Revista de Educação Física, 14. Obtido em 26 de junho de 2006 do World Wide Web: http://www.confef.org.br/.

EPIPHANIO, E. H. Psicologia do esporte: apropriando e desapropriando. Psicologia Ciência e Profissão, 19(3), 70-73. 1999.

GONÇALVES, M. P. Adaptação e validação da escala de motivação à prática de atividades físicas. Gonçalves, M. P. , Alchieri, J. C. Motivação à Prática de Atividades Físicas em Não-Atletas Psico-USF, v. 15, n. 1, p. 125-134, jan./abr. 2010. 